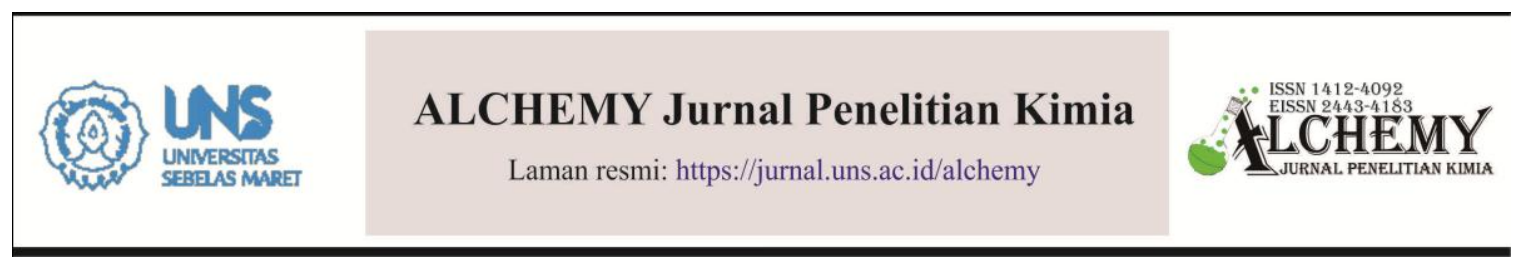

\title{
Pengaruh Jumlah Mol Kroslinker pada Selektifitas IIP Berbasis Polieugenol terhadap Fe(III)
}

\section{Muhammad Cholid Djunaidi ${ }^{*}$, Abdul Haris ${ }^{\mathrm{a}}$, Pardoyo Pardoyo ${ }^{\mathrm{a}}$, Rosdiana K}

${ }^{a}$ Departemen Kimia, Fakultas Sains dan Matematika, Univeristas Diponegoro, J1 Prof. Soedarto Tembalang Semarang, telp 024764474754

* Corresponding author

E-mail: choliddjunaidi@live.undip.ac.id

DOI: 10.20961/alchemy.14.2.12426.291-302

Received 23 July 2017, Accepted 27 August 2018, Published Online 03 September 2018

\begin{abstract}
ABSTRAK
Sintesis Ionic Imprinted Polymer (IIP) dilakukan dengan variasi penambahan crosslinker PEGDE (Polyethylene glycol diglycidilether) yang kemudian diuji selektivitas IIP terhadap ion logam Fe melalui proses adsorpsi. IIP merupakan metode mencetak ion logam yang terikat dalam polimer, selanjutnya dilepaskan dari matriks polimer menghasilkan cetakan yang sesuai terhadap ion target. Tujuan penelitian ini untuk menghasilkan IIP dan NIP dari polieugenol dengan variasi penambahan crosslinker PEGDE perbandingan sebanyak 1, 2 dan 3 mol, mengetahui pengaruh jumlah mol crosslinker terhadap selektivitas adsorpsi IIP yang melibatkan rongga imprint/cetakan, serta mengetahui pengaruh logam kompetitor terhadap selektivitas adsorpsi IIP terhadap logam Fe. Selektivitas adsorpsi ion logam Fe(III) dengan penambahan crosslinker PEDGE 3 mol lebih besar dibandingkan dengan penambahan crosslinker PEGDE 1 dan 2 mol. Selektivitas adsorpsi Fe lebih besar pada $\mathrm{Fe}-\mathrm{Cr}$ dibandingkan dengan $\mathrm{Fe}-\mathrm{Cd}$ dan $\mathrm{Fe}-\mathrm{Pb}$.
\end{abstract}

Kata kunci: adsorpsi, crosslinke, Ionic Imprinted Polymer (IIP), Non Imprinted Polymer (NIP), Polyethylene glycol diglycidilether (PEGDE)

\begin{abstract}
Influence of Crosslinker Mole Amount on the Selectivity IIP-Based Polyeugenol Towards Fe(III). The synthesis of IIP (Ionic Imprinted Polymer) was carried out using PEGDE (Polyethylene glycol diglycidilether) crosslinker addition in various moles which was then tested for IIP selectivity for Fe metal ions through the adsorption process. IIP is a method of metal ions printing which are bound in a polymer, then released from the polymer matrix to produce a suitable mold for the target ion. The purposes of this study were to produce IIP and non imprinted polymer (NIP) from polyeugenol with the addition of various moles of PEGDE crosslinkers as much as 1, 2 and 3 moles, and to determine the effect of the number of mole crosslinkers on the selectivity of IIP adsorption involving imprint/mold cavities; and the effect of competitor metals on IIP adsorption selectivity towards Fe metal. The selectivity of Fe (III) metal ion adsorption with the addition of 3 mole PEDGE crosslinkers was greater than the addition of 1 and 2 moles PEGDE crosslinkers. The selectivity of $\mathrm{Fe}$ adsorption is was greater in $\mathrm{Fe}-\mathrm{Cr}$ compared to $\mathrm{Fe}-\mathrm{Cd}$ and $\mathrm{Fe}-\mathrm{Pb}$.
\end{abstract}

Keywords: adsorption, crosslinker, Ionic Imprinted Polymer (IIP), Non Imprinted Polymer (NIP), Polyethylene glycol diglycidilether (PEGDE) 


\section{PENDAHULUAN}

Pencemaran logam berat telah menjadi masalah global seiring meningkatnya proses industrialisasi, aktivitas pertambangan dan laboratorium maupun kegiatan sehari-hari. Logam berat memiliki efek merugikan dalam lingkungan bahkan dalam konsentrasi yang sangat rendah. Tingginya kadar Fe (besi) yang terdapat didalam air memiliki pengaruh terhadap penggunanya antara lain konsentrasi Fe didalam air melebihi $1 \mathrm{mg} / \mathrm{L}$ akan menyebabkan warna air menjadi kemerah-merahan, menimbulkan noda pada peralatan dan bahan-bahan yang berwarna putih. Organisasi Kesehatan Dunia, WHO (World Health Organization) membatasi konsentrasi 0,3 mg/L besi pada air minum (Fan dan Sun, 2012).

Salah satu teknik terbaru yang dikembangkan untuk persiapan adsorben yang sangat efektif yaitu menggunakan IIP, dimana material sintesis mengandung situs reseptor sangat spesifik terhadap senyawa target (Parmpi dan Kofinas, 2004). Kelebihan dari IIP yaitu preparasinya mudah dan efektif untuk membuat media polimer yang mempunyai pengenal molekuler spesifik untuk senyawa target (Harera et al., 2015). IIP dapat mengenali dan mengikat ion target yang diinginkan dengan afinitas dan keselektifan tinggi, karena tingginya sifat taut silang polimer pada material IIP, maka sifatnya stabil dan kuat. Keselektifan IIP ditentukan salah satunya adalah keberadaan ion template dan agen crosslinking (crosslinker) (Lee, 2006).

Eugenol sebagai bahan alami Indonesia telah dimanfaatkan turunannya untuk pemisahan ion logam (Djunaidi et al., 2010). Eugenol dapat digunakan sebagai bahan awal sintesis suatu senyawa karena adanya tiga gugus fungsional yang terikat padanya, yaitu gugus alil, hidroksi dan metoksi. Melalui gugus alil, eugenol dapat dipolimerisasi menjadi polieugenol yang merupakan bahan awal untuk sintesis IIP (Djunaidi et al., 2016)

Dalam penelitian ini dilakukan sintesis IIP menggunakan polieugenol dengan variasi penambahan crosslinker PEGDE sebanyak 1, 2 dan 3 mol untuk uji selektivitas terhadap logam Fe.

\section{METODE PENELITIAN}

Tahap awal penelitian yang dilakukan yaitu sintesis polieugenol dari eugenol. Selanjutnya sintesis IIP dengan template ion Fe(III) yang kemudian dicrosslink menggunakan variasi penambahan PEGDE sebanyak 1, 2 dan 3 mol. Hasil yang diperoleh kemudian dilepas ion Fe-nya dengan bantuan asam, filtrat asam ditambahkan agen pengompleks KSCN yang selanjutnya diuji dengan spektrofotometer UV-Vis. Tahap terakhir yaitu percobaan adsorpsi melalui pengontakan adsorben dengan campuran logam 
biner Fe selama 24 jam. Filtrat hasil adsorpsi dianalisis dengan Atomic Absorbtion Spectrometer (AAS).

Peralatan gelas laboratorium, Peralatan refluks, Neraca analitik (Metter-200), Magnetic stirer, Spatula, pH meter (HACH E C20), Kertas saring halus, Spektrofotometer UV-Vis (Shimadzu), Spektroskopi Serapan Atom (AAS, Perkin Elmer), dan FTIR (Nicolete Avatar 360). Eugenol p.a (SIGMA Aldrich), $\mathrm{Na}_{2} \mathrm{SO}_{4}$ anhidrat teknis (Merck), $\mathrm{BF}_{3}$-dietileter (SIGMA Aldrich), $\mathrm{HCl}$ (Merck), $\mathrm{NaOH}$ p.a (Merck), Kloroform p.a (Merck), Metanol p.a (SIGMA Aldrich), Poly Ethilene Glycol Diglycidyl Ether (PEGDE) (SIGMA Aldrich), KSCN (Merck), Aquabides, $\mathrm{Fe}\left(\mathrm{NO}_{3}\right)_{3}$ (Merck), $\mathrm{Cr}\left(\mathrm{NO}_{3}\right)_{3}$ (Merck), $\mathrm{Pb}\left(\mathrm{NO}_{3}\right)_{2}$ (Merck), $\mathrm{Cd}\left(\mathrm{NO}_{3}\right)_{2}$ (Merck).

\section{Preparasi Bahan}

Pembuatan $\mathrm{HCl}$ 0,50 M, yaitu dilakukan pengenceran 16,70 mL $\mathrm{HCl} 3 \mathrm{M}$ dalam labu ukur $100 \mathrm{~mL}$ dengan akuades sampai batas miniskus. Pembuatan larutan $\mathrm{NaOH} 1 \mathrm{M}$, yaitu dengan melarutkan $4 \mathrm{~g} \mathrm{NaOH}$ dalam $100 \mathrm{~mL}$ akuades. Pembuatan larutan KSCN 1 M, yaitu dengan melarutkan 9,72 g KSCN dalam $100 \mathrm{~mL}$ akuades

\section{Sintesis Polieugenol (Djunaidi et al., 2010)}

Sebanyak 5,80 g (0,035 mol) eugenol dimasukkan dalam labu leher tiga kemudian ditambahkan $1 \mathrm{~mL} \mathrm{BF}_{3}$-dietileter $(0,008 \mathrm{~mol})$. Campuran diaduk menggunakan stirrer selama 4 jam dalam suhu ruang dan setiap 1 jam sekali dilakukan penambahan $\mathrm{BF}_{3}-$ dietileter sebanyak $0,25 \mathrm{~mL}$ (0,002 mol). Setelah reaksi tersebut berlangsung selama 12-16 jam, polimerisasi dihentikan dengan menambahkan $1 \mathrm{~mL}$ metanol. Gel yang terbentuk kemudian dilarutkan dengan kloroform dan dicuci dengan akuades hingga $\mathrm{pH}$ netral. Larutan tersebut kemudian dikeringkan dengan menambahkan $\mathrm{Na}_{2} \mathrm{SO}_{4}$ anhidrat. Setelah bebas dari air, larutan diuapkan pada suhu kamar. Endapan yang terbentuk kemudian dikeringkan dan ditimbang. Hasil yang didapat dianalisis dengan FTIR.

\section{Sintesis IIP variasi Penambahan Jumlah Crosslinker}

Polieugenol 0,50 g (0,003 mol) diaduk dengan ion Fe(III) $10 \mathrm{~mL} 50 \mathrm{ppm}$ yang telah dikondisikan pada pH 3 selama 24 jam, kemudian hasilnya disaring dengan kertas saring dan dikeringkan dengan dianginkan sampai kering. Polieugenol-Fe yang dihasilkan sebanyak 0,30 g dicrosslink dengan PEGDE (Polyethylene glycol diglycidilether) Mr 500 sebanyak 0,96 g ( $1 \mathrm{~mol}), 1,92 \mathrm{~g} \mathrm{(2} \mathrm{mol)} \mathrm{dan} \mathrm{2,88} \mathrm{g} \mathrm{(3} \mathrm{mol),} \mathrm{ditambahkan} \mathrm{katalis} \mathrm{NaOH} 1$ M sebanyak $20 \mathrm{~mL}$. Campuran direfluks dengan suhu $80-90^{\circ} \mathrm{C}$ selama 15 menit, hasilnya disaring dan dinetralkan dengan akuabides. Hasil endapan kemudian difurnace pada suhu $110^{\circ} \mathrm{C}$ selama 6 jam. Endapan sebanyak 0,30 g yang dihasilkan dilepaskan ion Fe(III) yang 
terikat dengan $10 \mathrm{~mL} 0,50 \mathrm{M} \mathrm{HCl}$ selama 24 jam dan filtrat asam tersebut ditambahkan agen pengkompleks KSCN yang kemudian diuji dengan spektrofotometer UV-Vis. Setelah filtrat tidak membentuk warna merah (6 hari) saat ditambahkan $\mathrm{KSCN}$, dilakukan penyaringan dan hasilnya (IIP) dikeringkan.

\section{Sintesis NIP}

NIP disintesis dengan cara yang sama dengan IIP tetapi tanpa pengikatan ion $\mathrm{Fe}$ (III) terlebih dahulu. Karakterisasi IIP dan NIP dilakukan dengan menggunakan FTIR.

\section{Sintesis NIP Asam}

Prosedur pembuatan NIP Asam sama dengan pembuatan NIP, akan tetapi pada akhir prosedur, 0,30 g polimer direndam dalam $10 \mathrm{~mL} \mathrm{HCl} \mathrm{0,50} \mathrm{M} \mathrm{dan} \mathrm{diaduk} 24$ jam selama 6 hari.

\section{Percobaan Adsorpsi}

Sebanyak $50 \mathrm{mg}$ adsorben dikontakkan dengan campuran $10 \mathrm{ml}$ ion $\mathrm{Fe}(\mathrm{III}) 10 \mathrm{ppm}$ dan ion kompetitor 10 ppm selama 24 jam dengan kecepatan konstan. Campuran disaring dengan kertas saring halus dan konsentrasi Fe(III) dalam filtrat dianalisa menggunakan AAS.

\section{Uji Selektivitas Adsorpsi}

Dilakukan pada adsorpsi kompetitif larutan biner yang terdiri dari $\mathrm{Fe}(\mathrm{III}) / \mathrm{Cd}(\mathrm{II})$, $\mathrm{Fe}(\mathrm{III}) / \mathrm{Cr}(\mathrm{III}), \mathrm{Fe}(\mathrm{III}) / \mathrm{Pb}(\mathrm{II})$ dan dibandingkan dengan NIP.

\section{HASIL DAN PEMBAHASAN \\ Sintesis Polieugenol}

Bahan awal yang digunakan untuk sintesis polieugenol adalah eugenol. Eugenol mempunyai 3 gugus fungsional yaitu alil, hidroksi, dan metoksi. Melalui gugus alil, eugenol dipolimerisasi menjadi polieugenol. Polimerisasi eugenol dilakukan dengan penambahan katalis $\mathrm{BF}_{3}$-dietileter. Reaksi polimerisasi dihentikan dengan menambahkan metanol. Mekanisme pembentukan polieugenol ditunjukkan pada Gambar 1.

Tahap inisiasi, katalis asam lewis $\mathrm{BF}_{3}$-dietileter menyebabkan reaksi adisi. Karbokation terbentuk karena adanya pemutusan ikatan rangkap pada gugus vinil eugenol. Karbokation ini mengalami penataan ulang yaitu terjadi pergeseran hidrida-1,2 yang menghasilkan karbokation lebih stabil. 
Tahap Inisiasi:

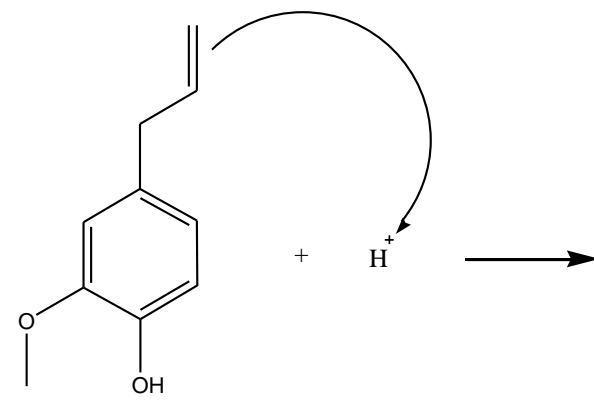

eugenol<smiles>CC[CH]Cc1ccc(O)c(OC)c1</smiles>

Karbokation

Tahap Propagasi:

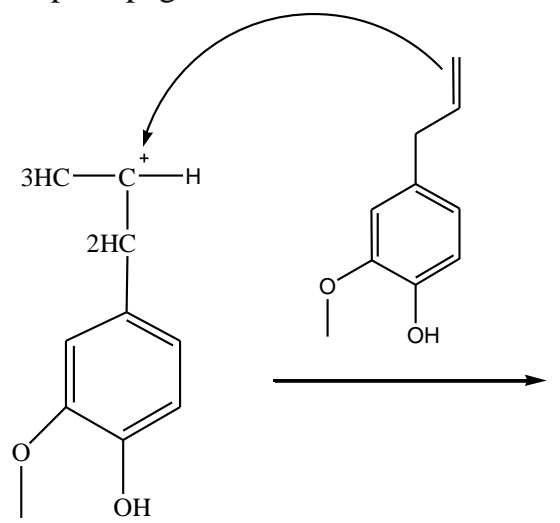

karbokation<smiles></smiles>

rantai polimer

Tahap Terminasi:

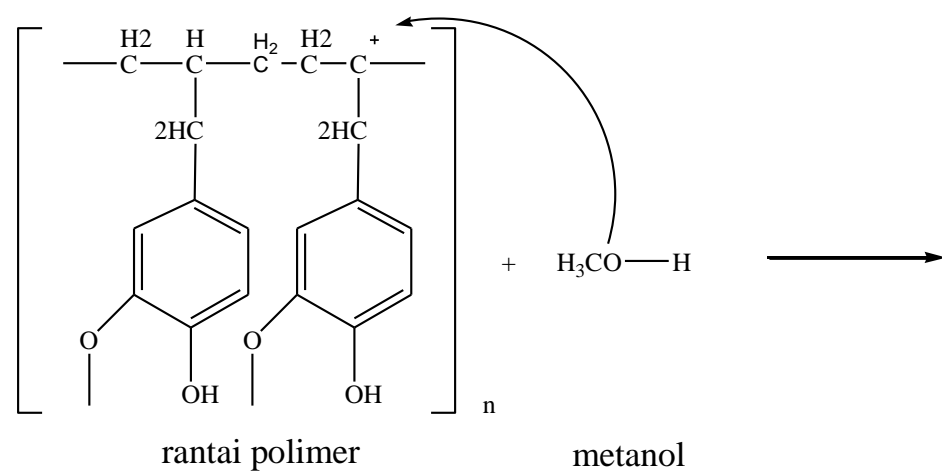

Gambar 1. Mekanisme pembentukan polieugenol (Djunaidi et al., 2010)

Tahap propagasi, terjadi pembentukan rantai dari monomer eugenol. Proses ini berkelanjutan sampai diperoleh rantai monomer yang panjang. Dalam tahap ini terjadi penataan intermolekuler dari karbokation.

Tahap terminasi dilakukan penambahan metanol untuk menghentikan proses polimerisasi. Penambahan metanol diharapkan pada ujung polimer polieugenol adalah gugus metoksi. Polieugenol yang dihasilkan berbentuk serbuk berwarna orange dengan rendemen $98,27 \%$. 


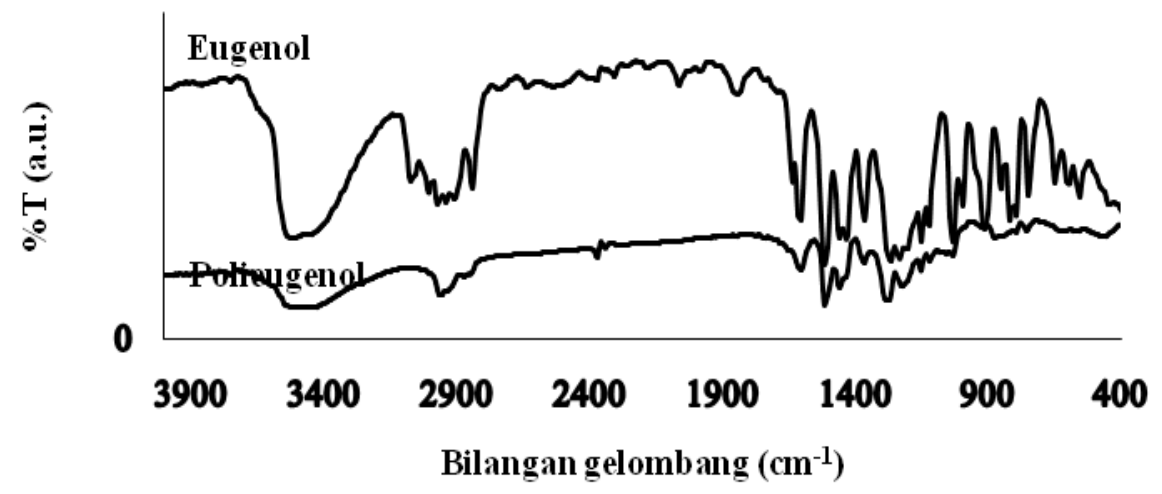

Gambar 2. Perbandingan spektra FTIR eugenol dan polieugenol

Pembentukan polieugenol ditunjukkan Gambar 2 dengan hilangnya serapan gugus vinil pada bilangan gelombang $995 \mathrm{~cm}^{-1}$ dan $910 \mathrm{~cm}^{-1}$. Hilangnya serapan $\mathrm{C}_{\mathrm{sp}}{ }^{2}-\mathrm{H}$ eugenol pada $3100 \mathrm{~cm}^{-1}$ memperkuat indikasi terjadinya polimerisasi (Djunaidi et al., 2010)

\section{Sintesis IIP Variasi Penambahan Jumlah mol Crosslinker}

Polieugenol hasil sintesis diikatkan dengan ion template Fe(III) $10 \mathrm{~mL} 50$ ppm pH 3 dengan cara pengkontakan selama 24 jam melalui pengadukan. Polieugenol-Fe kemudian dicrosslink dengan PEGDE (Polyethylene glycol diglycidilether) $\mathrm{Mr} 500$ sebanyak 0,96 g (1 mol), 1,92 g (2 mol) dan 2,88 g (3 mol). Campuran tersebut direfluks dengan suhu $80-90^{\circ} \mathrm{C}$. Selanjutnya ion $\mathrm{Fe}(\mathrm{III})$ yang terikat dilepaskan dengan cara pencucian menggunakan asam $(\mathrm{HCl})$ bertujuan untuk menghasilkan rongga cetakan/imprint. Hasil endapan dipanaskan dalam furnace pada suhu $110^{\circ} \mathrm{C}$ selama 6 jam dengan tujuan untuk menghilangkan molekul air yang tersisa. Reaksi pengikatan template Fe(III) pada polieugenol serta tahap selanjutnya untuk sintesis IIP ditunjukkan pada Gambar 3.

Pengujian kadar Fe yang terlepas dilakukan dengan penambahan KSCN sebagai agen pengompleks, filtrat akan berubah warna menjadi merah yang menandakan adanya logam Fe yang terlepas dari polimer. Reaksi yang terjadi yaitu:

$$
3 \mathrm{SCN}^{-}+\mathrm{Fe}^{3+} \rightleftarrows \mathrm{Fe}(\mathrm{SCN})_{3}{ }_{\text {(merah) }}
$$

Pengujian dilakukan hingga filtrat tidak terbentuk kompleks berwarna merah saat ditambahkan KSCN. Filtra hasil cucian dianalisis dengan spektrofotometer UV-Vis pada panjang gelombang $460 \mathrm{~nm}$ selama 6 hari. Hasilnya bisa dilihat pada Gambar 4 . 
Polimerisasi Polieugenol:

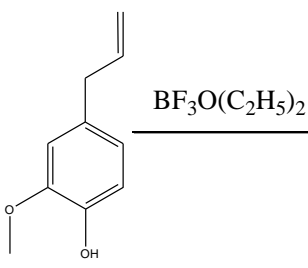

Eugenol

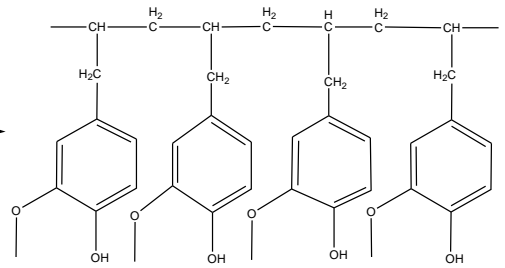

Polieugenol

Pengikatan Ion Cetakan, Fe(III):
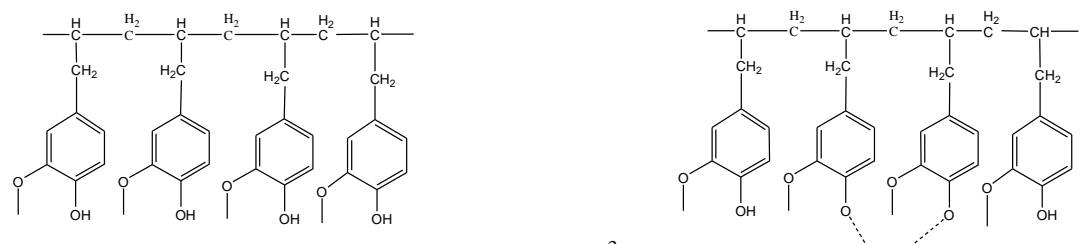

Template $\mathrm{Fe}^{3+}$

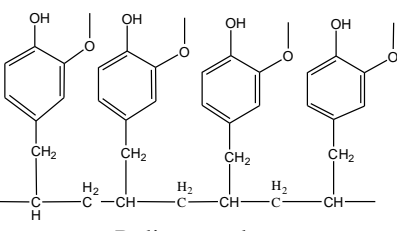

Fe

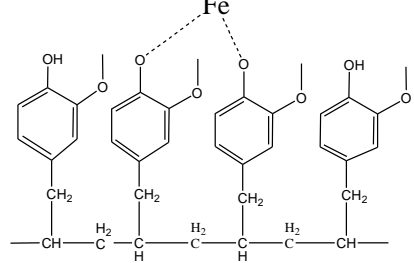

Polieugenol-Fe

Crosslinker, PEGDE:
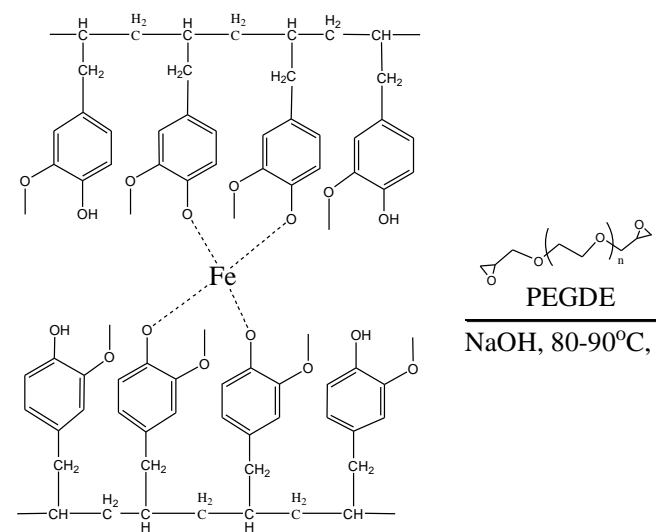

Polieugenol-Fe
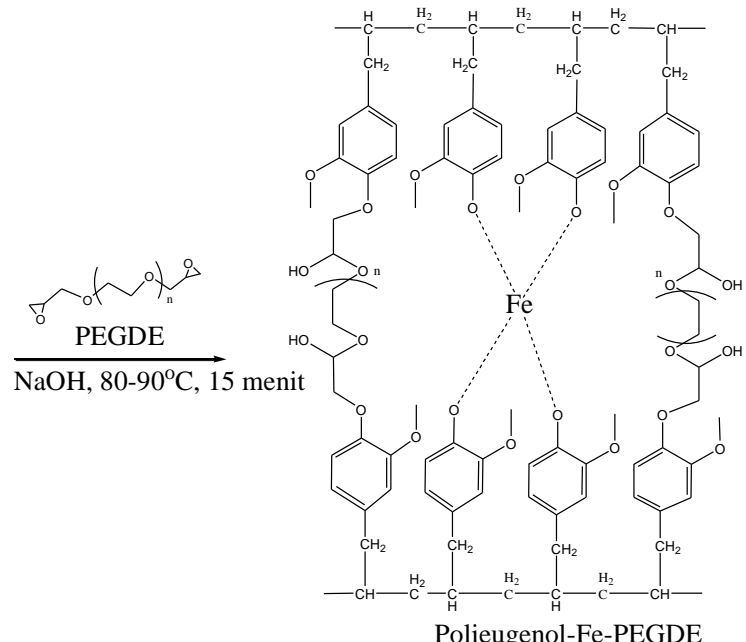

Pelepasan Ion $\mathrm{Fe}^{3+}$ :

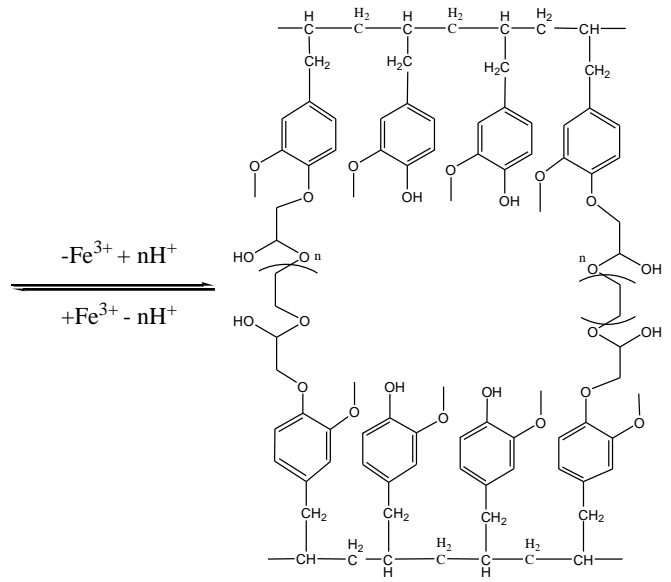

IIP

Gambar 3. Sintesis IIP Fe 


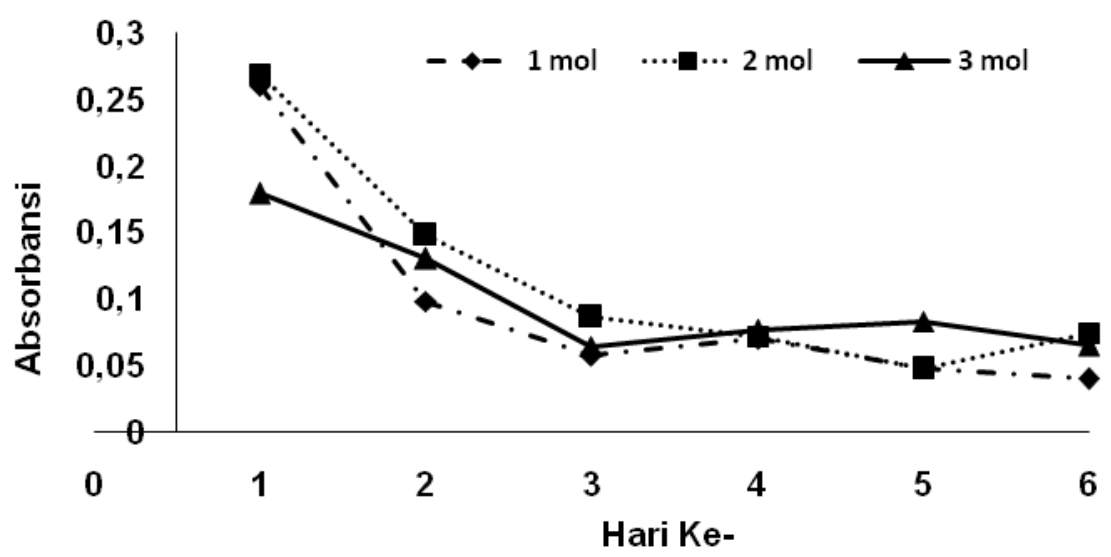

Gambar 4. Grafik pelepasan template Fe

Polimer dengan variasi penambahan crosslinker 1 dan 2 mol menghasilkan nilai absorbansi yang tinggi, hal ini kemungkinan disebabkan karena mudah lepasnya ion Fe(III) dari ikatan PEGDE dengan jumlah mol yang rendah ketika diasamkan dengan $\mathrm{HCl}$, sebaliknya dalam penambahan PEGDE 3 mol mengakibatkan ion Fe(III) terperangkap karena polimer yang meruah sehingga Fe(III) sulit terlepas. Polimer yang telah dilakukan pelepasan template kemudian dikeringkan dan dapat digunakan sebagai adsorben untuk mengadsorpsi logam.

\section{Sintesis NIP (Non Imprinted Polymer)}

Sintesis NIP prosedurnya sama dengan sintesis IIP hanya saja tidak dilakukan pengikatan ion Fe(III). Berikut skema reaksi pembentukan NIP (Gambar 5):
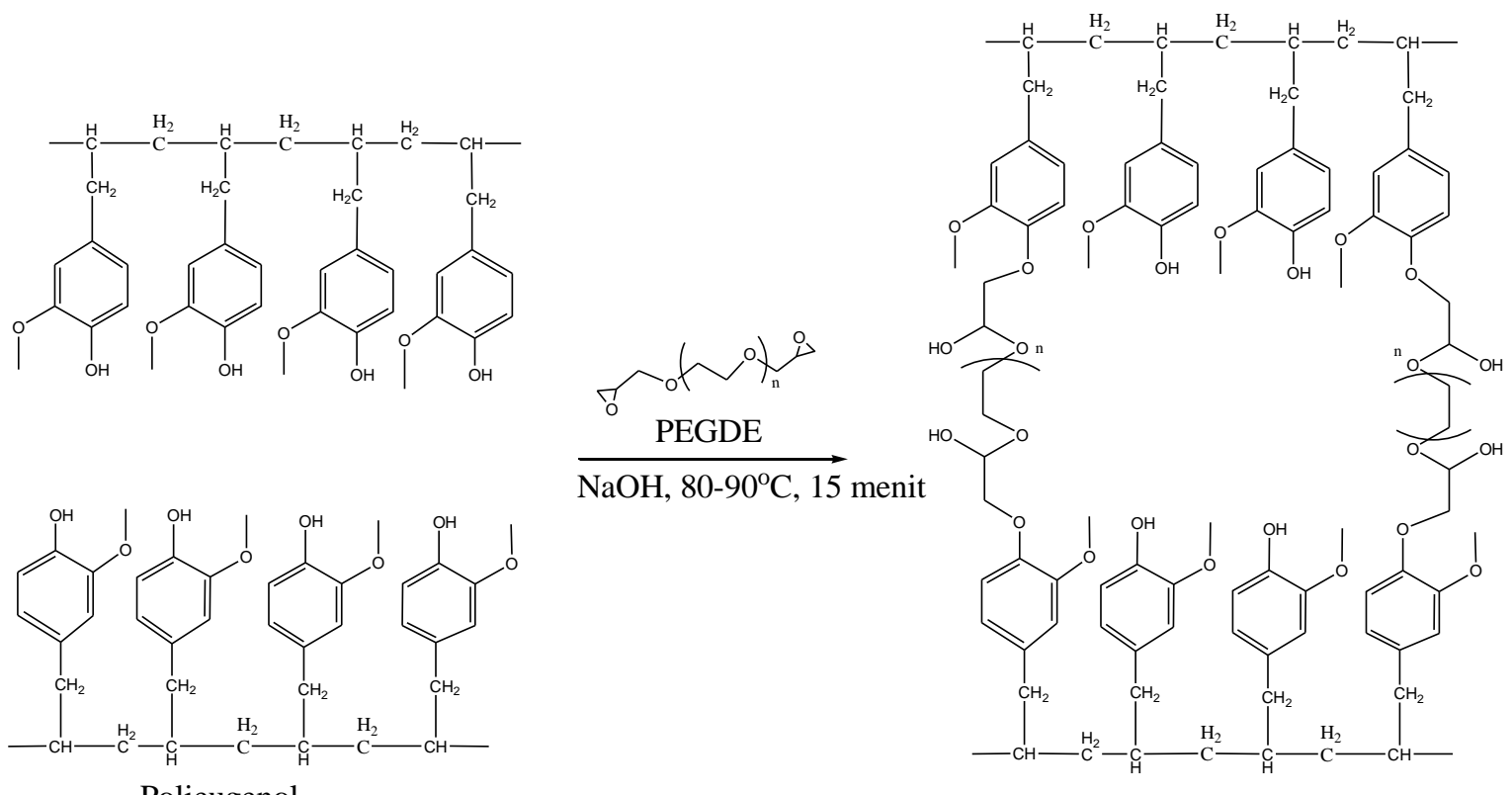

$\overrightarrow{\mathrm{NaOH}, 80-90^{\circ} \mathrm{C}, 15}$ menit

Polieugenol

NIP

Gambar 5. Skema Sintesis NIP

Hasil yang diperoleh selanjutnya digunakan sebagai adsorben untuk adsorpsi logam yang akan dibandingkan dengan adsorben IIP. 


\section{Analisis FTIR}

Hasil analisis menggunakan FTIR dapat diketahui bahwa serapan - OH pada polieugenol berkurang intensitasnya ketika digunakan berikatan dengan $\mathrm{Fe}(\mathrm{III})$ dan intensitas semakin menurun saat dicrosslink menggunakan PEGDE (Polieugenol-FePEGDE). Intensitas ini kemudian naik lagi setelah polimer Polieugenol-Fe-PEGDE dilepaskan ion cetakan $\mathrm{Fe}$ yang dikandungnya dengan asam $(\mathrm{HCl})$ menghasilkan IIP. Spektrum IIP lebih tajam daripada NIP dan NIP asam, menunjukkan peran $-\mathrm{OH}$ dalam kerja IIP. Hal tersebut dapat dilihat dari Gambar 6 s.d Gambar 8.

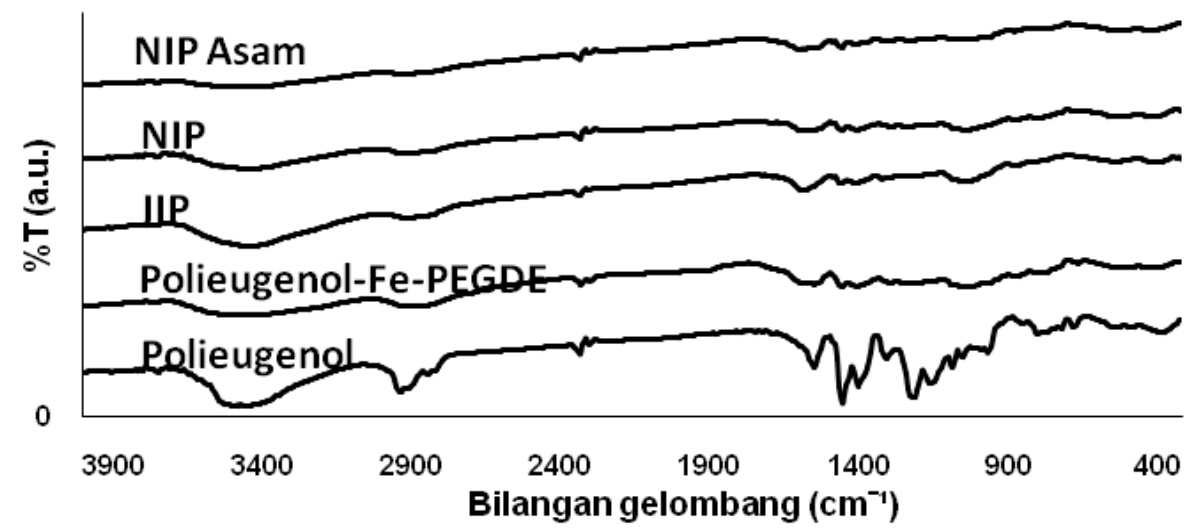

Gambar 6.Perbandingan spektra FTIR konsentrasi crosslinker $1 \mathrm{~mol}$

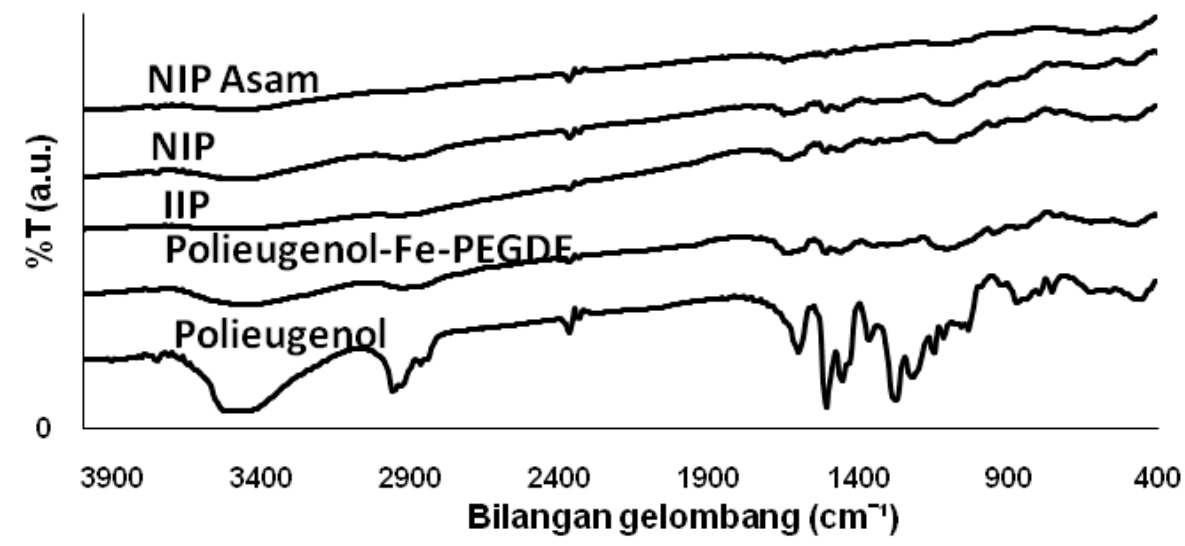

Gambar 7. Perbandingan spektra FTIR konsentrasi crosslinker 2 mol

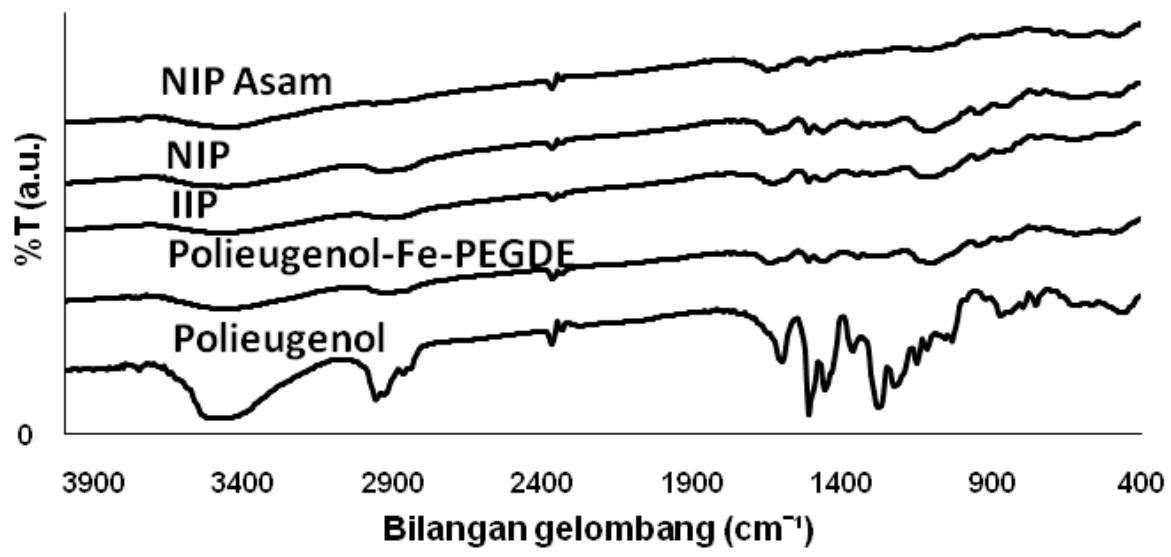

Gambar 8. Perbandingan spektra FTIR konsentrasi crosslinker 3 mol 
Perbandingan spektra FTIR IIP dan NIP variasi konsentrasi crosslinker dapat dilihat pada Gambar 9 dan 10 berikut:

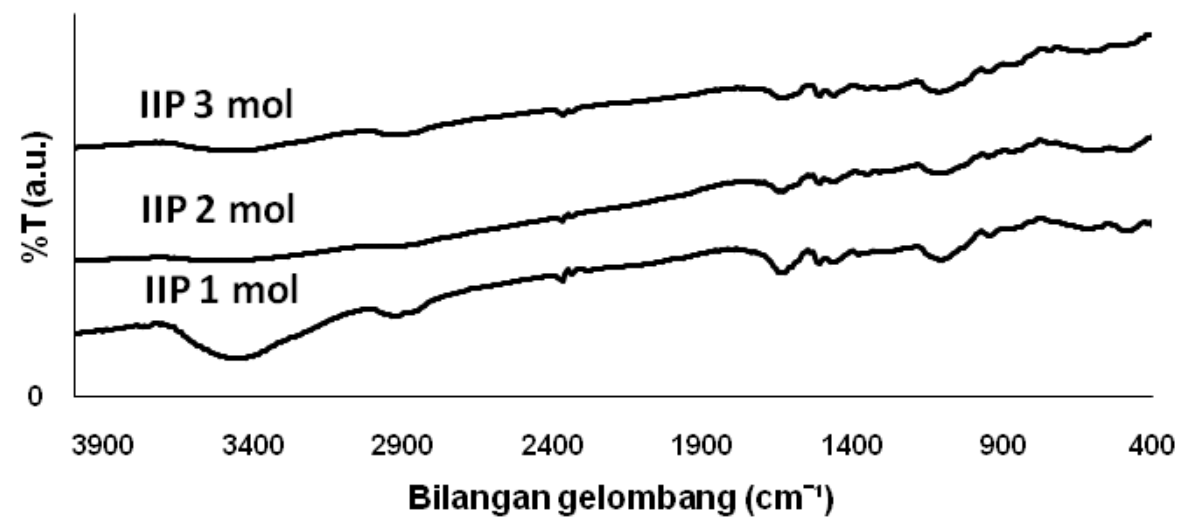

Gambar 9. Perbandingan spektra FTIR IIP variasi konsentrasi crosslinker

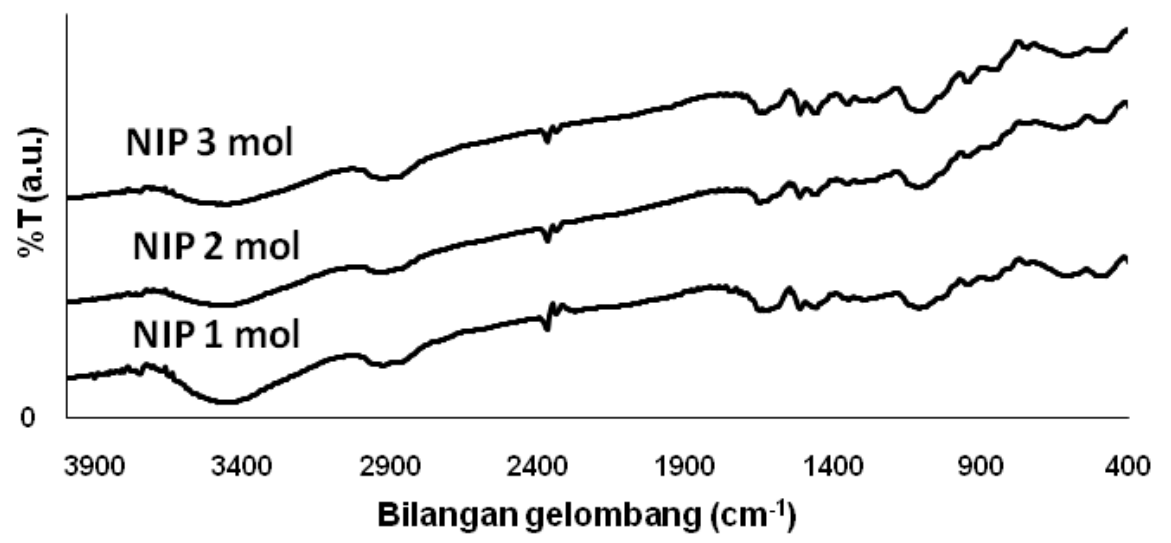

Gambar 10. Perbandingan spektra FTIR NIP variasi konsentrasi crosslinker

Nampak dari spektra FTIR (gambar 10) semakin besar konsentrasi crosslinker semakin berkurang intensitas spektra $-\mathrm{OH}$ pada kisaran $3500 \mathrm{~cm}^{-1}$, hal ini menunjukkan peran $-\mathrm{OH}$ di dalam pembentukan taut silang ini.

\section{Analisis BET}

Salah satu analisis luas permukaan pada polimer konsentrasi crosslinker 3 mol dilakukan dengan metode BET. Hasilnya adalah sebagai berikut: Polieugenol $=87,31 \mathrm{~m}^{2} / \mathrm{g}$; NIP $3 \mathrm{~mol}=37,63 \mathrm{~m}^{2} / \mathrm{g}$ dan IIP $3 \mathrm{~mol}=0,00 \mathrm{~m}^{2} / \mathrm{g}$. Terlihat bahwa terjadi penurunan luas permukaan dari polieugenol, saat di crosslink dengan PEGDE (NIP) maupun setelah menjadi IIP. Hal ini menunjukkan IIP telah mengalami reorganisasi dibandingkan polieugenol dan NIP. IIP $3 \mathrm{~mol}$ menghasilkan luas area $0,00 \mathrm{~m}^{2} / \mathrm{g}$ kemungkinan dikarenakan polimer yang mengalami shrinkage (penyusutan) yang mengakibatkan luas permukaannya sangat kecil. Penurunan luas permukaan ini dialami oleh peneliti lain diantaranya Buhani et al. (2010), Djunaidi et al. (2015), dan lain-lain. 


\section{Selektivitas Adsorpsi}

Selektivitas adsorpsi ion logam Fe berdasarkan variasi konsentrasi crosslinker dapat dilihat pada Tabel 1 .

Tabel 1. Selektivitas adsorpsi ion logam Fe berdasarkan konsentrasi crosslinker

\begin{tabular}{lrrrrrrrrr}
\hline \multirow{2}{*}{ Selektivitas } & \multicolumn{4}{c}{$\mathbf{1}$ mol } & \multicolumn{1}{c}{$\mathbf{2}$ mol } & \multicolumn{3}{c}{$\mathbf{3 ~ m o l}$} \\
\cline { 2 - 9 } & IIP & NIP & NIP asam & IIP & NIP & NIP asam & IIP & NIP & NIP asam \\
\hline Fe-Cr & 2,51 & 0 & 0 & 2,61 & 0,81 & 0 & 4,31 & 1,40 & 0,04 \\
Fe-Cd & 1,47 & 0,38 & 0,07 & 1,16 & 0,67 & 0,43 & 2,10 & 0,01 & 0,06 \\
Fe-Pb & 0,75 & 1,31 & 0 & 1,18 & 0 & 0 & 2,57 & 2,40 & 0 \\
\hline
\end{tabular}

Tabel 1 menunjukkan bahwa semakin besar konsentrasi crosslinker maka semakin selektif terhadap logam $\mathrm{Fe}(\mathrm{III})$. Hal tersebut kemungkinan terjadi karena semakin meruahnya polimer karena penambahan PEGDE, yang mengakibatkan semakin kecilnya pori-pori pada polimer sehingga selektivitas terhadap logam Fe besar, selain itu semakin banyaknya gugus aktif $-\mathrm{O}$ yang berasal dari PEGDE yang selektif terhadap ion $\mathrm{Fe}$ (Persson, 2010). Urutan selektivitas berdasarkan konsentrasi crosslinker polieugenol dengan agen crosslinking PEGDE adalah $3 \mathrm{~mol}>2 \mathrm{~mol}>1 \mathrm{~mol}$. Hasil yang diperoleh selektivitas adsorpsi $\mathrm{Fe}$ pada $\mathrm{Fe}-\mathrm{Cr}$ lebih tinggi dibandingkan pada $\mathrm{Fe}-\mathrm{Cd}$ dan $\mathrm{Fe}-\mathrm{Pb}$. Urutan tersebut cenderung mengikuti ukuran jari-jari atom terhidrat dari ion logam, dimana $\mathrm{Fe}(\mathrm{III})$ dan $\mathrm{Cr}$ (III) termasuk dalam kelompok asam keras yang memiliki jari-jari atom kecil yaitu jari-jari atom terhidrat $\mathrm{Fe}(\mathrm{III}) \quad 0,66 \AA$ dan $\mathrm{Cr}$ (III) 0,62 $\mathrm{A}, \mathrm{Cd}(\mathrm{II})$ masuk dalam kelompok asam lunak dan $\mathrm{Pb}(\mathrm{II})$ masuk dalam kelompok asam sedang yang umumnya mempunyai jari-jari atom besar, yaitu jari-jari atom terhidrat $\mathrm{Cd}$ (II) $0,96 \AA$ dan $\mathrm{Pb} 1,20 \AA$ (Persson, 2010). Hasil selektivitas adsorpsi Fe tertinggi pada $\mathrm{Fe}-\mathrm{Cr}$ ini menunjukkan bahwa sudah terbentuknya cetakan/imprint yang sesuai.

\section{KESIMPULAN}

IIP dan NIP dari polieugenol variasi penambahan crosslinker PEGDE sebanyak 1, 2 dan 3 mol berhasil disintesis.Selektivitas adsorpsi ion logam Fe(III) dengan konsentrasi crosslinker PEDGE 3 mol lebih besar dibandingakan dengan konsentrasi crosslinker PEGDE 2 mol dan 1 mol.Selektivitas adsorpsi Fe lebih besar pada logam biner $\mathrm{Fe}-\mathrm{Cr}$ dibandingkan dengan $\mathrm{Fe}-\mathrm{Cd}$ dan $\mathrm{Fe}-\mathrm{Pb}$. 


\section{DAFTAR PUSTAKA}

Buhani, N., Nuryono and Kunarti, E. S., 2010. Production of Metal Ion Imprinted Polymer from Mercapto-Silica Through Sol-Gel Process as Selective Adsorbent of Cadmium. Desalination 251(1): 83-89.

Djunaidi, M.C., Lusiana, R.A., and Kartikawati, N.G., 2010. Sintesis Polieugenol Dengan katalis $\mathrm{BF}_{3}$ Dietil eter dan $\mathrm{H}_{2} \mathrm{SO}_{4}$ Untuk Ekstraktan Logam Berat. Prosiding Seminar nasional Kimia dan Pendidikan Kimia 2010.

Djunaidi, M.C., Lusiana, R.A., Wibawa, P.J., Siswanta, D., and Jumina, J., 2010. Sintesis Turunan Poleugenol sebagai Carrier bagi Recovery Logam Berat dengan Teknik Membran Cair. Reaktor 13(1), 16-23.

Djunaidi, M.C., 2016. Adsorpsi dan transport selektif Fe(III) dan Fenol menggunakan Polieugenol sebagai Polimer tercetak Ion dan Molekul. Disertasi. Universitas Gadjah Mada.

Djunaidi, M.C., Jumina, J., Siswanta, D., and Ulbricht, M., 2015. Synthesis of Fe IonicImprinted Polyeugenol Using Polyethylene Glycol Diglycidilether as CrossLinking Agent for Sorption of Fe (III). Indonesian Journal of Chemistry 15(3), 305-314.

Fan, H.-T. and Sun, T., 2012. Selective Removal of Iron from Aqueous Solution using Ion Imprinted Thiocyanato-Functionalized Silica Gel Sorbents. Korean Journal of Chemical Engineering 29(6), 798-803.

Harera, L., Sudiarti, T., and Wulandari, M., 2015. Sintesis Cu(II)-Imprinted Polymers untuk Ekstraksi Fasa Padat dan Prakonsentrasi Ion Tembaga(II) dengan Ligan Pengkhelat 4-(2-Pyridylazo) Recorcinol. Al Kimiya 2(1), 30-39.

Lee, L.L., 2006. Synthesis and Application of Molecularly Imprinted Solid-Phase Extraction for The Determination of Terbutaline in Biological Matrices [QD382. I43 L732 $2006 \mathrm{f} \mathrm{rb].} \mathrm{Universiti} \mathrm{Sains} \mathrm{Malaysia.}$

Parmpi, P., and Kofinas, P., 2004. Biomimetic Glucose Recognition using Molecularly Imprinted Polymer Hydrogels. Biomaterials 25(10): 1969-1973.

Persson, I., 2010. Hydrated Metal Ions in Aqueous Solution: How Regular are Their Structures. Pure and Applied Chemistry 82(10), 1901-1917.

Svehla, G., 1985. Analisis Anorganik Kualitatif. ab L. Setiono dan Hadyana Pudjaatmaka. bagian II. edisi kelima. PT. Kalman Media Pusaka. Jakarta 369. 